\title{
O Cine Candelária
}

Teodoro Rennó Assunção Universidade Federal de Minas Gerais

\begin{abstract}
"C'est au fond le 'savoir' d'un spectateur que je convoque ici. Mais c'est le mien, c'est donc aussitôt quelque chose de ma vie qui a passé là.”

Jean Louis Schefer, L'homme ordinaire du cinéma
\end{abstract}

"Fechado o cinema Odeon, na Rua da Bahia.

Não é possível, minha mocidade fecha com ele um pouco.

(...)

Não aceito, por enquanto, o Cinema Glória, maior, mais americano, mais isso e aquilo.

Quero é o derrotado Cinema Odeon, o miúdo, fora de moda Cinema Odeon."

Carlos Drummond de Andrade, "O fim das coisas"

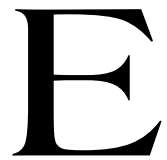

sta breve e saudosa fantasia amalgama estratos temporais diversos de um outro eu (também diverso) no tempo, mas caracterizado por um traço comum: a não inserção adulta no mercado de trabalho e a disponibilidade. Ela é variadamente detonada - cruel ironia! - todas as vezes em que, fazendo o percurso automobilístico de casa - no Sion - em direção ao campus da Pampulha, via Pedro II e Catalão, (eu) contorno a praça Raul Soares até a esquina onde decrépito e já desativado se situa o prédio do antigo Cine Candelária (agora só a casca da fachada). A memória de noitadas nos anos 80 é pré-ativada pela passagem na Bias 
Fortes quase chegando à praça onde outrora o glorioso $H i-f i$ (hoje esquálido Boehmioss) servia Pilsen-extras e bons pratos de resistência baratos, enquanto o ainda mais madrugadeiro Scaramouche servia também a bom preço carnes grelhadas bem feitas e cerveja gelada. As imediaçōes do Mercado Central lembram também os seus inúmeros botecos que servem tira-gostos (carnes bem aceboladas) com cerveja e, em sua mais distante proximidade, o antigo Tavares com suas carnes de caça proibidas, ou mesmo, na Curitiba, o heróico-nipo Tokyo com seus êxtases tranqüilos e relativamente baratos de teishokus regados a sakê, antes de sua súbita desaparição após um incêndio suspeito conectado na época à exploração "mafiosa" de máquinas de video-poker. A passagem pela Olegário Maciel (onde um segundo mercado dispõe também de seus inúmeros bares) reaviva a memória mais remota do inteiramente desaparecido Cine Texas (com sua programação faroeste-pornô) assim como a memória bem mais recente do notívago e hardcore Vagalume com suas desafinadas e precárias bandas tocando ao vivo para a fauna majoritária de putas, travestis e gigolôs. Enfim, pouco antes da chegada da esquina do Candelária, reminiscências de leituras já antigas de Valéry Larbaud (terá sido no Barnabooth ou no Jaune bleu blanc?), descrevendo ocioso (e feliz no detalhe) as praias do golfo de Nápoles, são evocadas pelo nome de bom augúrio do pequeno, ordinário e resistente Hotel Sorrento.

Se avançássemos na praça até a outra esquina, chegaríamos a um bar outrora elegante (cujo nome agora me escapa) com seu balcão largo e mesas/cadeiras de madeira hoje já desaparecidos, e, virando na Augusto de Lima, iríamos em direção ao há muito defunto Cine Roxy (antigo Cine Democrata) e ao campo cruzeirense do Barro Preto, bandas hoje frequentadas apenas enquanto me encaminho pra ver algum filme em fim de carreira no Cineclube/sinuca/bar La Bocca. Passando pela Amazonas (onde lá no alto, já quase com Contorno, a Juiz de Fora guarda hoje um Haus München com promissoras cervejas incrementadas), poderíamos enfim virar de novo na Olegário Maciel subindo, onde, no térreo do JK, ao lado de uma Assembléia de Deus, o subterrâneo e abafado Matrix já foi palco de shows udi-grudi (que, alcoolizado e sonolento, quase-recentemente presenciei) como o de Jards Macalé ou os das bandas de rock mineiras "Último Número" e "Divergência Socialista". 
Mas é o Cine Candelária que - como majestoso alvo involuntário desta forçosa e quase diária flânerie automobilística matutina - declancha a multifacetada fantasia do ócio cinematográfico. Ainda no finalzinho dos anos 90 foi possível acompanhar sua melancólica derrocada final de prédio quase abandonado (com sua pintura azul claro toda descascada) onde a partir das duas da tarde era possível assistir com um único ingresso - promoção terminal do já quase cadáver ilusionista - a dois filmes pornôs fajutos cujos títulos mal se deixavam anunciar nos letreiros pretos (ou vermelhos) banguelos e cujos cartazes de duvidosa obscenidade já haviam se retirado para o interior da sala de espera. Nem mesmo à tarde ou começo da noite era mais possível ver um carrinho de pipoca ou baleiro ambulante que fosse e a discreta bilheteria, sob cujas gradinhas era inverossímil pressupor a presença de uma alma contábil enclaustrada, parecia completamente desertada. Logo pela manhã um vago desejo de abandono de qualquer projeto de vida (ou do árduo e incompleto fazer que resulta em minúsculas obras) assumia a forma nonchalante e sonhada do cinéfilo diletante que, a partir das dez ou onze horas da manhã, na poli-oferta parisiense de cinema, já pode penetrar na sala escura para seguir - esquecido dos afazeres e justificado pela boa qualidade do divertissement - um filme de um qualquer festival de autores como os irmãos Lumière, Dziga Vertov, Jean Vigo ou Renoir (a lista, não fingidamente clássica e educativa como esta, poderia ser longa e conter, por exemplo, os experimentos mais contemporâneos de Andy Wahrol, Michael Snow, Hollis Frampton, Margueritte Duras ou Guy Debord). A desolada paisagem belo-horizontina desmente, porém, num instante, esta há não tanto tempo (ou seja: no meio dos anos 90) ainda aberta - mas rarissimamente realizada - possibilidade. Ela se assemelharia antes - pelo possível mas aqui rarefeito público semi-proletário ou desempregado - a um cinema popular com repertório ordinário funcionando desde as onze da manhã na Münzstrasse na Berlim do fim dos anos 20 (cf. "Cinéma dans la Münzstrasse" de Siegfried Kracauer ${ }^{1}$ ). Este público triste

${ }^{1}$ KRACAUER, 1995. 
- numeroso na Berlim dos anos 20, mas que, em Belo Horizonte no fim dos anos 90, não passaria certamente de uma extraordinária e excêntrica meia dúzia de pessoas - seria ainda hoje composto por pessoas que, nos termos de Siegfried Kracauer, "não sabem o que fazer do seu tempo."

Longe, no entanto, de haver sido sempre assim. Dos relatos de mãe e tias que moças o frequentaram ao longo dos anos 50 , onde (então um cine bem-afamado no centro geométrico do plano original da cidade de $\mathrm{BH}$ ) puderam assistir - se não falha a memória delas - sobretudo a filmes mexicanos e espanhóis, até minha certamente esquecida primeira vez no fim dos anos 60 (talvez algum filme comemorativo da Copa de 70) e, primeira vez de que ainda consigo me lembrar, o então (1972) recém-lançado Horizonte perdido, que impressionou profunda e seriosamente o préadolescente começando a degustar uma vaga inquietação metafísica e uma tolamente romântica e insuspeita sede de absoluto, até, enfim e ainda no plano do cinema sério, o encontro já adolescente pré-marxista, com um primo distante (então envolvido com o movimento estudantil) no filme $O$ assassinato de Trotsky de Joseph Losey - bela e então importante lição de anti-stalinismo - em uma sessão exemplarmente vazia das quatro horas da tarde de um dia útil. Já no plano da iniciação erótica, caberia citar o filme A estrela sobe de Bruno Barreto, visto também já adolescente com a expressa intenção de ver os peitinhos (e talvez a boceta cabeludinha) de Betty Faria, que desarmou e surpreendeu com a até então desconhecida estória comovente do romance de Marques Rebelo (seria alucinação a sensação de lágrimas ou de algum estranho aprendizado sobre o mundo?).

Antes, porém, de finalizar o breve relato do reduzido repertório de filmes vistos no Candelária de que ainda me lembro, seria útil talvez - nesta precária tentativa de resgate parcial do lembrado - citar alguns filmes memoráveis a partir do fim dos anos 60 e ao longo da década dos 70, vistos em outros cines da cidade, mas que a verossimilhança não impediria de todo que tivessem sido vistos lá: $O$ dólar furado com Giuliano Gema, visto

${ }^{2}$ KRACAUER, 1995, p. 102. 
com o mais chegado dos primos, e Tubarão do Spielberg, numa das raras vezes com o pai (o que dizer do fiasco de um lento e existencial-burguês Antonioni visto com ele no Cine-clube da FACE?) no sólido e central Cine Brasil; $O$ destino de Posseidon, visto com este mesmo primo - filme catastrófico que, ao espectador sair, desperta a algo fácil sensação de alívio de se saber são e salvo - no Cine Royal; a Odisséia com Kirk Douglas, visto com uma prima chegada e coetânea, numa alegre e com o filme radiosa manhã de domingo (pré-estréia ou sessão infanto-juvenil?) no Cine Jacques, então ao lado do saudoso Ted's com seus hot-dogs longos com batata frita; As 24 horas de Le Mans com Steve Mcqueen, visto com um antigo colega (mau aluno, doidão e muito bom de bola cf. o infanto-juvenil do Atlético) que nunca mais vi, no sempre confortável e de boa acústica Cine Paladium; o Canal 100 inesquecível que, visto com não sei mais quem no majestoso Cine Metrópole, mostrou a derrota e desclassificação (já semifinal do Robertão?) no Mineirão do Cruzeiro para o Fluminense por 1 x 0, gol de Mickey; Irmão Sol, Irmã Lua de Zefirelli, visto com o irmão (em assombro cristão) no Cine Tamoio; $O$ estranho no ninho com Jack Nicholson, visto com o irmão também no Cine Paladium; Ojovem Frankenstein com Martin Feldman e Mel Brooks, visto também - em agradável sessão da tarde - com o primo mais chegado no hoje remoto Cine Guarany; Butch Cassidy e, pouco depois, O golpe de mestre com Paul Newman e Robert Redford, respectivamente no Paladium e no Guarany; O fantasma da liberdade de Buñuel, visto por mim sozinho e então perplexo (como quando da contemporânea leitura dos contos d'O muro de Jean-Paul Sartre) no Cine Pathé, assim como aí também o Amarcord de Fellini, visto com o então recém-conhecido e agora o mais antigo amigo de colégio (e esta lista, com alguma pesquisa e arranjos de verossimilhança, poderia se estender indefinidamente, mesmo que continuasse a não incluir todo o Godard, Pasolini, Antonioni, Glauber Rocha, Wim Wenders, Herzog, Sganzerla e muitos outros vistos no cineclube da FACE ou na Humberto Mauro...). 


\section{II}

É a figura do antigo companheiro na experiência adolescente de voyeurismo pornô no Candelária - um primo algo afastado com os dois sobrenomes de meu pai, colega bonito, inteligente e muito bom de bola, que morava com os pais (como eu na rua Aimorés com Santa Catarina) na rua Mato Grosso quase com Aimorés, não muito longe da praça Raul Soares - quem me desperta, por associação prévia e imperiosa, esta outra e mais tardia (já com mais de 18 anos) recordação de um uso estranho do cinema (em que o esperado repertório pornô quase se apaga diante do fenômeno maior que é estar sentado olhando a tela naquela sala escura) sob o efeito do haxixe. Banhados na irresponsabilidade ou indiferença acadêmica e inspirados por um nihilismo alegre e uma disponibilidade meio boba e em via de extinção para aventuras banais, já fizéramos, rindo de loucura fácil, experimentos haxixins de flâneries bicicléticas pelo centro de Belo Horizonte às três e meio ou quatro horas da madrugada. Lembro-me então também de alguns "experimentos" para obter sob o haxixe no cinema - e aqui no Cine Candelária que alcançávamos a pé - não a estranheza de uma outra "realidade" por imersão no simulacro (ou representação), mas a estranheza anterior e enquadrante de estar em Belo Horizonte, no Cine Candelária, na tarde de um dia útil, assistindo com um amigo vadio a um pornô ordinário, até que esta mínima localização e situação, sob uma onda mais forte da procela haxíxica se perdesse de súbito em uma apavorante desorientação e não-saber. $\mathrm{O}$ frisson metafísico quanto ao espaço e o onírico desejo de sair do cinema em uma outra cidade nos levava, depois de uma troca rápida de palavras e já meio saturados do geme-geme do fuck, a abandonar a sala para confirmar a estranheza ordinária de estar na terra (que planeta é este afinal?) em Belo Horizonte no Cine Candelária, mas onde enfim? Estes "experimentos" livres, no entanto, não visavam nenhuma pesquisa por contraste sobre o funcionamento da consciência normal tal como a realizada por Henri Michaux e descrita em "Le merveilleux normal" (em Les grandes épreuves de l'esprit). ${ }^{3}$ Os flashes desconexos e fulgurantes

${ }^{3}$ MICHAUX, 1966. 
desta forjada e quase nunca alcançada iluminação haxíxica - quanto ao absurdo de estar no mundo e quanto a um não mais reconhecer este mundo e um não mais saber onde se está - tornavam-se logo, na ausência de qualquer registro e formalização, mera poeira de uma embriaguez amnésica que consumia tempo sem quase nada dar em troca além da corrosiva moleza e apatia.

O que de fato sempre me chamou primeiramente a atenção em "Le merveilleux normal" de Henri Michaux - que pode retrospectivamente ter contaminado ou deformado com seu filtro exegético a memória larvar de alguns "experimentos" despretensiosos de dois ingênuos universitários nihilistas - é menos o conteúdo, certamente surpreendente, da experiência da desorientação, do que sua bizarra localização em um cinema. $\mathrm{O}$ que ocorre a Michaux sob o efeito do haxixe? Uma estranha e desconhecida (e enfim intolerável) falta: a de saber em que cidade do mundo ele estava; e, ao reencontrar Paris ("Paris, rive gauche, tout bonnement." ${ }^{4}$ ) saindo do cinema, a continuidade intermitente da perda da situação em que se encontra ou como ele mesmo define então: "O que se passava? Eu estava desorientado. O que quer dizer isso? Desordenadamente desorientado por desorientações múltiplas, incessantes, incessantemente diferentes, imprevisíveis; desconcertado por interrupções de orientação. Era preciso que eu bem o reconhecesse: desde meu nascimento eu tinha passado a maior parte do meu tempo me orientando. Obrigatoriamente vigilante, golpeado sem trégua pelos estrépitos, os choques, os chamados que de todas as partes sinalizam, advertem, alertam, eu tinha, como qualquer homem, sido obrigado desde sempre a precisar a situação em que me encontrava, a fazê-lo várias vezes por segundo, a refazê-lo, navio no meio do estranho, do estrangeiro, forçado a estas indispensáveis operações para me manter em estado de conhecimento da situação indefinidamente mutante." 5

São, porém, pinceladas breves, comuns e vagas - de um paisagista pouco interessado na crônica autobiográfica direta - as que definem a situação em que a crise de orientação ocorre: "Um dia, no cinema, após ter

\footnotetext{
${ }^{4}$ MICHAUX, 1966, p. 10.

${ }^{5}$ MICHAUX, 1966, p. 10.
} 
tomado haxixe, como eu seguia na obscuridade um filme anglo-saxão (...)" ${ }^{6}$, sem que jamais saibamos que filme anglo-saxão era aquele, qual cinema na rive gauche e qual dia (não seria então noite - ou seja: "Un soir (...)" -, mas que dia da semana ou do fim de semana?), alimentando assim a ociosa curiosidade do leitor e abrindo-lhe a fantasia de uma deliciosa disponibilidade do escritor e pesquisador Henri Michaux, então frequentador diurno de cinemas. Uma semelhante e nonchalante disponibilidade - para a leitura, a música ou a contemplação solitária parece enquadrar a maior parte dos minuciosos relatos sobre os efeitos de alucinógenos (e, em particular, de mescalina) cuja pesquisa cuidadosa e exaustiva é matéria - além das notaçōes poéticas de Paix dans les brisements (1959) - de quatro densos livros de relatos e reflexões: Misérable miracle (La mescaline) (1956), L'infini turbulent (1957), Connaissance par les gouffres (1961) e Les grandes épreuves de l'esprit (1966). O "disponível escritor”, que prepara então seu vigésimo livro: Les grandes épreuves de l'esprit (1966), é já sexagenário (nascido em 1899), apesar de inaposentável como artista, também artista plástico cuja primeira exposição data de 1937 , e - antes das relativamente tardias "viagens" por meio de drogas - grande viajante do mundo: Savannah, Norfolk, Newport-News, Rio de Janeiro, Buenos Aires (1920); um ano no Equador (1927); Turquia, Itália, África do Norte (1929); "enfim sua viagem" em 1930-1931 na Índia, Indonésia e China; Lisboa (1932); Montevidéu e Buenos Aires (1937); Brasil (Minas Gerais e Estado do Rio) em 1939; Saint-Antoine e Le Lavandou (19401942); Egito (1945-1946); Estados Unidos, Roma e Londres (1957) e ainda muitos outros lugares posteriores não inscritos nas "Algumas informações sobre cinqüenta e nove anos de existência” ("Quelques renseignements sur cinquante-neuf années d'existence" $)$, e que - nesta mesma mini(auto)biografia agora citada - registra já em 1921: "Métiers e empregos diversos, medíocres e mediocremente exercidos.", 8 depois em

\footnotetext{
${ }^{6}$ MICHAUX, 1966, p. 9.

7 MICHAUX, 1983.

${ }^{8}$ MICHAUX, 1983, p. 13.
} 
1925: "Empregos diversos. Algum tempo em uma editora a serviço da fabricação.", 9 e enfim em 1938-1939: "Ocupa-se da revista Hermè̀", ${ }^{10}$ sem que, no entanto, sejam precisados o quando e o como o escritor e artista conquista o decisivo direito ao ócio para dedicar-se sempre insatisfeito e incompleto à plena aventura da composição das obras. Mas pode-se, ainda assim, ter acesso a um flash biográfico sobre o cinéfilo Henri Michaux, no começo de seu retrato ("Michaux: A paixão do exaustivo") por E. M. Cioran: "Há uns quinze anos, Michaux me levava regularmente ao Grand Palais onde eram exibidos todos os tipos de filmes de caráter científico, alguns curiosos, outros técnicos, impenetráveis. Para dizer a verdade, o que me intrigava era menos as projeções do que o interesse que mostrava por elas. Não compreendia muito bem o motivo de uma atenção tão obstinada. Como, não cessava de me perguntar, um espírito tão veemente, voltado para si mesmo, em perpétuo fervor ou frenesi, conseguia se entusiasmar por demonstrações tão minuciosas, tão escandalosamente impessoais?" 11

Mas, assim como Ulisses perde o senso de orientação ao chegar à ilha Eéia, não sabendo mais onde o sol se levanta e onde se põe, e, depois da descida ao Hades, de volta à ilha de Circe, reconhece estar no Oriente, assim também os dois jovens experimentadores nihilistas, após a não de todo explicitada experiência de desorientação no cine Candelária, alucinam precariamente sob o efeito do haxixe ornamentos e arabescos pseudoorientais tanto em bazares de quinquilharias (segundo Henri Michaux: "detalhes no detalhe; rendados no rendado; continuação monótona"12) quanto nos jogos melancólicos das colunetas de água da hoje extinta fonte luminosa do jardim (parádeisos) da praça Raul Soares, extraordinariamente sensíveis aos fugidios e em B.H. improváveis "minaretes" evidenciados pelo cânhamo [e alimentando, na extremidade oposta do círculo da praça ao

9 MICHAUX, 1983, p. 15.

${ }^{10}$ MICHAUX, 1983, p. 15.

${ }^{11}$ CIORAN, 1986, p. 91.

${ }^{12}$ MICHAUX, 1967, p. 18. 
modernoso (e outrora chique) edifício Casablanca, por entre cervejas e bagaceiras no bar (com balcão e mobiliário de madeira escura) Marrocos (agora sim o nome), uma fantasia qualquer haxíxica retirada inconseqüente, ingênua e romanescamente d'O quarteto de Alexandria de Lawrence Durrel ou da leitura espaçada e preguiçosa - quem sabe? sob uma pseudo-palmeira empoeirada da praça - de Omar Khayam, Hafez e aqui e ali de algo d'As mile uma noites, de Jorge Luis Borges ou das Nourritures terrestres de André Gide], pois, como lembra com pertinência Henri Michaux em "Como agem as drogas?" ("Comment agissent les drogues?"), "são os fustes incrivelmente gráceis das aparições haxíxicas que deram a idéia, o princípio, o jeito dos jatos d'água filiformes, dos graciosos arcos geminados, das colunetas, dos arcos sobreelevados, dos minaretes e não o Islã que de maneira nenhuma os continha, como também não continha as estalactites ambíguas e vibrantes de seus frontispícios e seus 'arabescos' sem fim, exemplos dos ornamentos com infinitas variações, da fina ornamentificação incoercível das visóes haxíxicas, de seus diamantes misturados." 13

\section{III}

Diferentemente do Cine Pathé - cuja história já pode hoje ser consultada em $A$ sala dos sonhos de Carlos Armando ${ }^{14}$ (ou mais recentemente também em Cine Pathé de Celina Albano ${ }^{15}$ ) - o Cine Candelária, inaugurado em 11 de dezembro de 1952 com capacidade para 2000 pessoas (cf. O fim das coisas ${ }^{16}$ ), aguarda ainda um registro sistemático da sua programação e frequência até o final da década de 90. Em O fim das coisas: as salas de cinema de Belo Horizonte, há, além dos dados já citados sobre sua inauguração, apenas a seguinte informação servindo de legenda a uma foto

${ }^{13}$ MICHAUX, 1967, p. 22.

${ }^{14}$ ARMANDO, 1999.

15 ALBANO, 2008.

${ }^{16}$ BRAGA, 1995, p. 56, nota 60. 
provavelmente do começo dos 80: "Prédio do Cine Candelária, um dos maiores cinemas da cidade. Foi bastante freqüentado nos anos 60 , quando possuía instalações modernas e confortáveis aliadas a uma programação de qualidade." ${ }^{17} \mathrm{Na}$ ausência da memória de uma experiência direta ou de uma pesquisa em jornais, o pouco que pude saber da programação dos anos 60 me chegou por meio de testemunhos orais: um crítico de cinema belohorizontino - da turma antiga do CEC - lembrava ter visto mais de um Godard (Pierrot le fou, Alphaville?) no Candelária, enquanto um aficcionado soixante-huitard de blues e rock-and-roll lembrava ali de matinées dominicais com shows da "Jovem Guarda" onde certa vez na entrada ganhara um inesquecível beijo da hoje esquecida (e breguíssima) cantora Vanusa. Não é, porém, minha intenção fazer um registro detalhado e objetivo da história desta sala de cinema, mas apenas um relato circunstanciado de algumas experiências pessoais que, como já indicado, datam somente do início dos anos 70 .

Uma possível caracterização genérica do que ocorre às salas de cinema belo-horizontinas a partir sobretudo do meio dos anos 70 é a sugerida pelo título do capítulo IV de O fim das coisas: "decadência". A massificação dos hábitos televisivos e - por meio de uma novidade tecnológica decisiva - a introdução do hábito cômodo e doméstico do home video com todo o novo comércio das videolocadoras ("matou o cinema e foi à família", segundo reza a precisa e jocosa fórmula), aliadas a uma crescente e rápida deterioração urbana do centro da cidade, geram uma situação (cujo abandono e mal-estar é insistente em filmes coetâneos de Wim Wenders como Im Lauf der Zeite The summer in the city) que é descrita resumidamente da seguinte maneira em O fim das coisas: "Várias salas do circuito comercial com suas instalações sucateadas pelo descaso de seus proprietários passaram a se dedicar à exibição de produções de qualidade duvidosa, como filmes de artes marciais e pornochanchadas. (...) Na seqüência, os filmes que exploravam a violência e a pornografia - em sua maioria produçóes de baixo

17 BRAGA, 1995, p. 75. 
orçamento - tomaram de assalto as salas de cinema populares. Com isto, essas salas perderam boa parte de seu público habitual." 18

Dos cines que optaram então pela exibição de filmes pornográficos poderíamos deixar de lado os menos conhecidos que na década de 70 não duraram mais do que dois anos como o Boa Vista (na avenida Elísio de Britto), o Santa Rita (na rua Coronel Alves), o Montanhês (na rua Guaicurus), o Pio XII (no bairro da Glória) e o Saci (na rua Tamoios) (cf. $O$ fim das $\operatorname{coisas}^{19}$ ). Mas não poderíamos deixar de mencionar - memorizando ainda uma vez o já e para sempre desaparecido - alguns nomes de cines que a partir da década de 70 compuseram a (consultável em jornais) oferta semanal belo-horizontina de cinema pornográfico: $\mathrm{o}$ - pensado a princípio para filmes de arte - Regina (na rua da Bahia), o Texas (na avenida Olegário Maciel), o Miami (na rua Guaicurus), o Las Vegas (na rua Padre Belchior), assim como os mais antigos e outrora participantes de um circuito comercial não-degradado: o México, o Tamoio, o Art-Palácio e o Candelária. O seguinte balanço numérico é expressivo: 1) “(...) no início da década de 80, o número de salas em atividade no país era a metade do que existia nos anos 50", 2) em Belo Horizonte, "em 1985, existiam 18 cinemas, sendo que 12 exibiam filmes pornográficos." (cf. O fim das coisas ${ }^{20}$ ).

Um breve parêntese deve, no entanto, corrigir uma grave omissão na história (meio oficiosa) das salas de cinema de Belo Horizonte proposta por O fim das coisas: a da existência de salas populares (onde se pagava a metade do preço das salas chiques) com programação pornográfica já na década de 10, salas saborosamente então denominadas "cine-poeira", segundo um testemunho indireto (o de Paulo Augusto Gomes) que paradoxalmente as deixa no inglório anonimato: "Havia, ainda, os chamados 'cines-poeira', designação da época para salas de má qualidade, quase sempre situadas em zonas impróprias (do baixo meretrício ou boêmia), que programavam filmes, seguidos muitas vezes de 'shows' ao vivo, onde mulheres semi-nuas

18 BRAGA, 1995, p. 77.

19 BRAGA, 1995, p. 77.

${ }^{20}$ BRAGA, 1995, p. 78-79. 
se exibiam em números de dança do ventre, maxixe e outras do mesmo gênero. Obviamente havia resistência - e forte - a esse tipo de espetáculo, levando o poeta Carlos Drummond de Andrade a relembrar no poema 'A difícil escolha': 'Cada manhã, a liga pela moralidade / serviçal, pontual / indica os filmes que podemos ver, / os prejudiciais, os com reserva, / os inofensivos."'21

Apesar de Paulo Augusto Gomes não indicar sua fonte de informação (e de não termos para Belo Horizonte os dados organizados e descritos das salas e sessões de cinema, como o fez para São Paulo até 1914 Vicente de Paula Araújo em Saloes, circos e cinemas de São Pauloº ${ }^{22}$, é possível colher em Beira-mar (Memórias 4) de Pedro Nava uma espécie de confirmação desta informação (ainda que, infelizmente, indireta e não muito detalhada). Esta ad- ou supra-informação de Pedro Nava sucede uma primeira descrição de uma sessão de cinema (ainda mudo) no Cine Odeon, dos jogos e cervejas no Clube Belo Horizonte e da zona de meretrício para onde enfim aqueles homens do começo dos anos 20 do século passado desciam. Eis o que diz então o narrador: "Conforme ficara combinado, no outro sábado reunimonos à mesma hora, o Paulo, o Cavalcanti e eu - enriquecidos pela companhia do Isador - decididos a programa mais grandioso. Íriamos ao Éden, o famoso cabaré da Olímpia. Em vez do Odeon, fomos ao Comércio, velho pulgueiro da rua Caetés, freqüentado pela turcalhada das lojas da vizinhança e suas famílias. Esse cinema era o segundo na hierarquia dos de Belo Horizonte. Abaixo dele vinha o Floresta - aliás o mais velho da cidade. Os outros ainda estavam nos limbos. Tinha havido um, na Zona, o Parque Cinema, alguma coisa como a Cervejaria Dona Amélia, ao Mangue, onde os habitués viam filmes enquanto cervejavam. Só que o de Belo Horizonte era melhor: só passava fita de sacanagem. Infelizmente não conheci essa casa grandiosa, que fez furor na segunda década, senão na saudosa reminiscência de velhos boêmios da cidade."23

${ }^{21}$ GOMES, 1997, p. 353.

22 ARAÚJO, 1981.

${ }^{23}$ NAVA, 1985, p. 61-62. 
Mas, ainda que não explícito nos filmes e no ambiente em que eram projetados, o erotismo magnetizava também (dentro, embora, das convençōes burguesas) a atmosfera e as sessões do Cine Odeon. Dos cartazes de filmes da Nordisk, colados nas paredes empapeladas de verde e vermelho do vestíbulo do Odeon, Pedro Nava nos diz o seguinte: "Lembro dum, particularmente. Representava cena de teatro onde se via, no palco recurvo, a figura duma mulher em espartilho, rendas aparecendo por baixo, um pouco das grossas coxas e das ligas verdes segurando meias pretas que se perdiam em altos canos de botinas claras. Um enorme chapéu e pleureuse. Arredondava boca de canto, dedinho no ar e era devorada pelos olhares de senhores no camarote rente ao palco, de que um dirigia os raios do monóculo aos regos do seio da artista e o outro, mais para baixo, para o ponto apontado pela ponta do colete devant-droit. A mulher parecia com as heroínas de nossos livrinhos de safadezas no colégio." ${ }^{24} \mathrm{O}$ começo ou antecomeço das sessões era um momento privilegiado de flerte (assim como o footing que as sucedia descrito no final deste primeiro capítulo): "Antes da luz apagar, era costume dar um espaço de tempo para as famílias se repararem. A orquestra afinava. (...) Como vários rapazes, o Paulo, eu e o Cavalcanti permanecíamos de pé e corríamos os olhos nas moças sentadas entre seus pais e mães e tias solteironas. Isoladas como dentro duma vitrine. Os leques se agitavam, subia um perfume de pó de arroz e os namorados começavam a trocar suas greladas ofidianas. De repente eu vi luzirem (positivamente luzirem!) uns cabelos de ouro. Eram curtos e viravam-se em duas pontas da face levemente picada de sardas de uma menina de narizinho arrebitado cujos olhos escuros contrastavam com o metal de sua cabeça. Foi como se eu assistisse uma flor desabrochar, um cristal se precipitar, nascer uma estrela, subir o sol. Tive a impressão de uma pedrada no peito, coração galopando no peito. Quando eu ia perguntar aos amigos quem era, a luz apagou, começou a projeção." 25 Em Drummond também lemos algo assim

${ }^{24}$ NAVA, 1985, p. 49.

${ }^{25}$ NAVA, 1985, p. 50-51. 
- ainda que poeticamente condensado - na descrição melancolicamente saudosa do Cine Odeon em "O fim das coisas" (com itálicos meus):

"A espera na sala de espera. A matinê com Buck Jones, tombos, tiros, tramas.

A primeira sessão e a segunda sessão da noite.

A divina orquestra, mesmo não divina, costumeira. O jornal da Fox. William S. Hart.

As meninas de familia na platéia.

A impossivel (sonhada) bolinação, pobre sátiro em potencial." 26

Voltemos agora ao nosso ponto. O que a foto do Candelária provavelmente no começo dos anos 80 revela é um formato de programação pornô que ainda testemunhei no fim dos anos 90: segundo dois cartazes acima dos letreiros habituais e mesmo do nome em linha de metal preenchida por finas e longilíneas lâmpadas elétricas (Cine Candelária) "sempre 2 FILMES; CENAS DE SEXO EXPLÍCITO DO COMEÇO AO FIM somente para público adulto" (cf. O fim das coisas ${ }^{27}$ ). O que um cartaz fixo acima dos cambiáveis letreiros ordinários anuncia é um formato (ou material) pornô onde - como também nos visíveis letreiros "cambiáveis" de cines como o Tamoio ("filme erótico com cenas de sexo explícito") e México ("filmes pornográficos com cenas de sexo explícito HOJE / A vingança do dragão chinês", aqui em modelo de dois gêneros; cf. O fim das coisas $^{28}$ ) - pouco importam o nome do filme, o do diretor ou dos atores principais e mesmo - o que faz muitas vezes dos preparativos rápidos e romanescamente inverossímeis do fuck e chupadas algo grotesco e sem nenhuma graça - a estória, que, desconsiderada, está sempre (e toscamente) a serviço da nudez e da consumação carnal que motivam como objeto o olhar curioso do voyeur.

${ }^{26}$ Apud BRAGA, 1995, p. 2.

27 BRAGA, 1995, p. 75.

${ }^{28}$ BRAGA, 1995, p. 65. 
Se o termo "erótico" parece no caso destes filmes um eufemismo (já que reservável apenas a "obras de arte" como o Decameron de Pasolini ou o Império dos sentidos de Mishima), o termo "pornográfico", ao designar algo que é objeto de compra e venda - ainda que como imagem ou representação (isto é: Ersatz, simulacro) da coisa - para a satisfação do desejo ou da excitação sexual, parece adequado à idéia de "prostituição" (ou de "prostituta", pórnç em grego), neste caso, dos atores que vendem a imagem de seus corpos "em busca do orgasmo". Seria, no entanto, difícil e descabido categorizar esteticamente (ou seja: no plano das "belas artes") a excitação sexual produzida por um filme ou - o que vai no mesmo sentido - censurar, como um desvio patológico em relação a um modelo ideal, um orgasmo obtido solitariamente ou pelo toque manual de um outro (como na "pegação") a partir da contemplação voyeurística excitada de um filme pornô. Como categorizar, por exemplo, a mistura de nojo e excitação ou interesse (análoga à que se daria quando da leitura d'Os cento e vinte dias de Sodoma do Marquês de Sade ou d'As onze mil vergas de Apollinaire) em meio a uma parca e pouco à vontade platéia sedenta de prazer fácil - de quem, como eu, viu Caligula (com o MacDowell do Laranja mecânica) no começo dos anos 80 no Cine Candelária? Ou como censurar - mesmo admitindo a funda tristeza da ausência de um parceiro sexual/erótico efetivo - a "animalidade baixa" de uma descarga orgasmática obtida através da masturbação solitária ou recíproca de quem se excita semipublicamente vendo um pornô numa sala escura de cinema (onde se ouvem gemidos de outros e se sente o cheiro enjoativo de esperma)?

Mesmo que uma estimativa precisa de classes sociais que compunham a frequentação do Cine Candelária nos anos 70 (sobretudo a $2^{\mathrm{a}}$ metade) e 80 ainda restasse como informação a ser obtida através de penosa pesquisa, seria possível avançar (com alguma chance de acerto) uma característica comum - além do interesse específico por sexo e pornografia - daqueles frequentadores de sessōes vespertinas em dias úteis da semana: a disponibilidade de tempo e energia sexual (ou - mais ou menos radicalmente - a não-sujeição ao trabalho). Mas se para os destituídos que estão à margem do trabalho - como aquele Lumpenproletariat que frequentava as sessōes matinais da Münzstrasse de Berlim do fim dos anos 20 - o "desemprego" é certamente 
signo de degradação social, é urgente, por outro lado, tentar recuperar - através de um operador dissonante como Georges Bataille - a disponibilidade para o sexo e a "animalidade bestial" (oposta à humanização servil do trabalho) como signo de soberania. Em "Kinsey, a escória e o trabalho", analisando com alguma cautela metódica os dados do Relatório Kinsey sobre a frequência hebdomadária de orgasmos, Georges Bataille chega às seguintes conclusões: "Só a escória, ou seja, só aqueles que não trabalham e cujo comportamento equivale globalmente a uma negação da 'humanidade', apresenta uma proporção de 49,4\% de alta frequiência. (...) Globalmente, o índice varia segundo a maior ou menor humanização: quanto mais humanizados estão os homens, mais reduzida é a sua exuberância. Precisemos: a proporção de altas frequiências é de 15,4\% nos trabalhadores; 16,1\% nos operários não qualificados; de 12,1\% nos operários qualificados; de $10,7 \%$ nos 'mangas de alpaca' inferiores; de 8,9\% nos superiores. Uma única exceção a esta regra: ao passar dos empregados superiores às profissões importantes que correspondem às classes dirigentes, o índice sobe mais de 3 unidades para atingir $12,4 \%$. (...) O sentido deste aumento, no que diz respeito à classe dominante, é claro: essa classe conhece, relativamente às outras categorias, um mínimo de ociosidade e a riqueza média de que goza não corresponde necessariamente a um tempo de trabalho excepcional; por isso dispõe de um excesso de energia, superior ao das classes trabalhadoras." 29 G. Bataille, na sugestiva nota de pé da página 143, se pergunta então: "Em certa acepção, que é a classe dominante senão a escória que conseguiu a felicidade, ainda por cima aceite e consentida por todos os outros?” A epígrafe de Balzac para este ensaio - uma citação por Bataille de Splendeurs et misères des courtizanes de Balzac - formula exemplarmente a questão sob um outro ponto de vista: "Daí a ociosidade que devora os dias; pois os excessos no amor exigem descanso e refeições reparadoras. Daí esse ódio pelo trabalho que obriga essas pessoas a procurarem meios rápidos de arranjar dinheiro."30

\footnotetext{
${ }^{29}$ BATAILLE, 1980, p. 142.

${ }^{30}$ BATAILLE, 1980, p. 133.
} 


\section{IV}

Se, agora, em meio às já podres ruínas de memória, tento voltar um instante à minha freqüentação em meados dos anos 70 e começo dos 80 do Cine Candelária, é preciso fazer um corte que coincide não com os 18 anos completados (dando acesso legal à entrada em qualquer filme), mas com a obtenção (já com corpo e cara possíveis de alguém com 18, apesar de apenas com 16) de uma carteirinha de cinema da UMES com data de nascimento falsificada, resultado auspicioso da convivência com os cineclubistas de esquerda do movimento estudantil secundarista, o que no ano de 1977 (em que ganhamos com uma chapa de oposição o Grêmio do Colégio Santo Antônio) foi marcado precisamente pela reativação do cineclube neste colégio com a seguinte programação "cabeça” escolhida por mim: Quando o carnaval chegar de Cacá Diegues, Noites de cabiria de Fellini, O evangelho segundo São Mateus de Pasolini, Em busca do ouro de Chaplin, Roma cidade aberta de Rosselini e O golpe de mestre com Paul Newman e Robert Redford (o único a atrair muitos estudantes e lotar duas vezes a sala).

Obviamente também depois de 1977 (e já com os 18 anos completos), como deixa claro a segunda seção sobre o cinema sob o efeito do haxixe, continuei, juntamente com a intensificação da cinefilia cineclubística (sobretudo o cine-clube da FACE e a Humberto Mauro), a freqüentar ocasionalmente o Cine Candelária, não tendo perdido de todo o inconfessável interesse voyeurístico (apesar de sua urgência ter amainado um pouco com a iniciação sexual aos 16/17 com paqueras e a primeira namorada) por belas mulheres peladas e cenas de sexo (o mais das vezes mal) representadas, ainda que a sensibilidade acrescida ao arbitrário das tramas, à inconsistência das personagens e ao mau acabamento formal generalizado começasse também a me fazer evitar um pouco o trash da pornochanchada e depois também do pornô. Como exemplos quase apenas de títulos (de filmes de que eu me esqueci quase inteiramente) poderia citar rapidamente Elas são do baralho (1977) de Sílvio de Abreu, estrelando Antônio 
Fagundes ${ }^{31}$; algum filme do estranho gênero (criado no Brasil por Antônio Polo Galante) do "confinamento de mulheres" tal como (mas qual seria precisamente?) Presídio de mulheres violentadas (1976) de A. P. Galante ou Pensionato das vigaristas (1977) de Osvaldo de Oliveira ou Reformatório das depravadas (1978) de Ody Fraga; Embalos alucinantes (A troca de casais) (1979) de José Miziara com Nuno Leal Maia e o já bem grisalhudo Anselmo Duarte impagável como senhor devasso (em uma trama picante que sugere "ousadamente" o swing e o adultério como formas legítimas de combater o tédio conjugal); Histórias que as nossas babás não contavam (1979) de Osvaldo de Oliveira com a gostosa mulata Adele Fátima como Chapéuzinho Vermelho, o ridículo Costinha como caçador e sete anōes sacanas só pensando naquilo (em conjunto com pretensões ao cômico chulo, mas descambando mesmo para o grotesco involuntário); Mulher objeto (1980) de Sílvio de Abreu, com Nuno Leal Maia e Helena Ramos, em trama análoga (uma mulher frígida com o marido, mas tendo prazer intenso na infidelidade cometida com vários outros parceiros sonhados) à de A dama do lotação (1978) de Neville de Almeida, com Sônia Braga e o mesmo Nuno Leal Maia; o estranhíssimo e então marcante Snuff-Vitimas do prazer (1977) de Cláudio Cunha, com Carlos Vereza e a musa carioca Rossana Ghessa e a paulista Nadyr Fernandes (com roteiro inspirado em uma reportagem da revista Manchete sobre filmes clandestinos que mostravam as atrizes sendo estupradas e assassinadas de verdade); Mulher mulher (1979) de Jean Garret, com Helena Ramos em cena inesquecível (e prenunciadora da zoofilia mais hardcore) sendo lambida no pescoço por um cavalo; ${ }^{32}$ Noite das taras (1980), filme em três episódios dirigidos por

${ }^{31}$ Em cujo folder de divulgação podemos ler: "Baseado em um roteiro de Georges Feydeau, mistura o duplo sentido do teatro de revista, a crítica de costumes da comédia urbana, o humor irreverente das histórias em quadrinhos, a alegria descompromissada de um circo de cavalinhos." (ABREU, 2006, p. 79-80). 32 Filme do qual emerge como único e kitschíssimo fragmento a seguinte frase de uma mulher: "Eu não quero ser apenas um receptáculo do esperma matrimonial.” (ABREU, 2006, p. 110). 
Ody Fraga, John Doo e David Cardoso, onde se destaca a nudez atraente de Matilde Mastrangi; já transitando para o pornô explícito Oh! Rebuceteio (1982) de Cláudio Cunha, O círculo do prazer (1982) de Mário Vaz Filho (cujo pseudônimo cretino era $\mathrm{H}$. Romeu Pinto) e, enfim, para matar a perversa curiosidade zoofilica, algum título (qual precisamente?) como $U m$ jumento em minha cama ou Emoçôes sexuais de um jegue que hoje associo quase automaticamente à cena do Asno de ouro de Apuleio em que a matrona romana - após the murmurar "Cupio" ("Te desejo") e "Sine te jam vivere nequeo" ("Não consigo mais viver sem ti”) ${ }^{33}$ ou, já mais próxima, "Teneo te", "teneo, meum palumbulum, meum passerem" ("Te tenho, meu pombinho, meu passarinho" $)^{34}$ - goza plenamente se deixando penetrar pelo avolumado e rijo órgão do asno narrador.

É, porém, antes de 1977, ou seja: entre 1974 e 1976, quando (ainda recém-adolescente sem carteirinha falsificada) um simples pedido de documento representava uma humilhante exclusão, fazendo da entrada no cinema um momento de alto e adrenalínico risco que fazia suar frio e acelerava desordenadamente o coração, que o fascínio da ostensiva transgressão à lei se combinava com o da moralmente "indevida" (apesar de leve) iniciação sexual ao nu feminino, dando ao Cine Candelária uma aura rubra de mistério que depois jamais ele teria de igual maneira. Lembro-me, por exemplo, de um porteiro gordo e careca (trajando um terno puído, dizendo, impaciente ante a tímida hesitação minha e do primo que é o personagem da segunda seção, "entra logo!", "entra logo!" e nós apressando o passo e contendo o riso que estoura na sala semi-escura quase deserta de uma modorrenta sessão das duas da tarde. Este exemplo sinaliza bem que, apesar de eventuais barradas na porta (que então, para não dar na cara, nos afastavam dali durante meses), pois os porteiros variavam muito em seu rigor ou capricho, o Cine Candelária era em geral bem tolerante com os meninotes crescidos que éramos nestes anos longínquos. Mas, como a frequentação bem esporádica nos parecia então (talvez não tão paranoicamente)

\footnotetext{
${ }^{33}$ APULÉE, 2007, p. 438.

${ }^{34}$ APULÉE, 2007, p. 440.
} 
a melhor tática, nesta breve e tremorizante época de ouro não cheguei a assistir lá senão a algumas poucas pornochanchadas.

Além do já citado A estrela sobre de Bruno Barreto (e talvez também - ou seria apenas o trailer? - Guerra conjugal baseado em Dalton Trevisan), consegui apenas relembrar vagamente a presença vibrante de algumas gostosas atrizes peladas (apenas algumas individuadas e reconhecidas) - e como o mero ver atento imagens filmadas já me dava então tanto prazer (sempre à expectativa de uma improvável e fugidia boceta cabeluda) - e algumas tiradas que durante um breve e tolo tempo usei como piadas picantes sem-graça em encontros de jovenzinhos solitários que só pensam em sexo: em Ainda agarro esta vizinha (1974) de Pedro Carlos Rovai, o conquistador (que observa da janela de seu apartamento a futura conquista no andar de baixo) come um omelete, enquanto ela tem um sorvete na mão, e ele diz pra ela: "Vamos trocar? Eu te dou os meus ovos e você me deixa chupar o seu sorvete."; em Secas e molhadas (1975) de Mozael Silveira, o herói vai à cozinha, coloca dois ovos na frigideira e pergunta para a mulher onde ela enfiou a linguiça dele. Relendo sinopses rápidas de filmes em algum capítulo perdido de uma História do cinema dos anos 70, reconheci também a graça boba que achei na estória de "O despejo" de Adriano Stuart, um dos episódios de Cada um dá o que tem (1975), em que um casal de namorados é atacado por quatro assaltantes no instante em que o rapaz tentava convencer a moça a fazer sexo com ele dentro do carro; os assaltantes decidem violentar não a moça, mas o rapaz, que aparece na cena seguinte todo maquiado (à la Ney Matogrosso nos "Secos e Molhados") e com gestos femininos.

Se a nudez de Betty Faria em $A$ estrela sobe e a de Sônia Braga em Dona Flor e seus dois maridos (que vi com o primo mais chegado na primeira vez em que estive em Salvador) ainda hoje se destacam e quase ganham autonomia em relação aos filmes em que ocorrem, a nudez lindíssima de Vera Fischer em um filme que não consegui mais identificar (e que não é, como pude verificar depois, nem Anjo loiro nem Superfêmea nem Macho e fêmea nem As delícias da vida nem Essa gostosa brincadeira a dois) é quase a única lembrança que dele tenho além das circunstâncias bizarras (ou cena) 
em que ela se manifesta: na cama com horríveis (mas, presume-se, bemdotados) e lúbricos anões. O efeito contundente (que definirei melhor na sequência) da cena vinha, parece-me agora, do vivíssimo contraste entre a deformidade daqueles seres diminutos e a graça inefável e pulsante daquele jovem e lindíssimo corpo feminino (da qual em sua jovem lindeza e gostosura talvez apenas Nicole Puzzi se aproxime) de quem já fora, antes de completar 18 anos e não sem alguma justiça, Miss Brasil e finalista de Miss Universo. Lembro-me também, um pouco vaga e cruelmente, de um certo mal-estar e nojo (diante da cena grotesca) impressos na fisionomia da atriz, que não os conseguia de todo disfarçar (como se pronunciando sua futura carreira séria de cinema e telenovela); e de eu então sentir também, como se por transmissão magnética, um certo mal-estar e perplexidade (o que pensar então dos inumeráveis granículos de poeira naquela grande sala suja, dançando aleatórios em meio a um jato abafado e quente de luz vespertina irrompendo por alguma fresta?) que, já acabado o filme e fora do cinema, quando do comentário com o primo-amigo da rua Mato Grosso, se resolveu súbita e surpreendentemente no irrefutável prazer de uma gostosa gargalhada.

Visto à distância, este desejo adolescente meio autônomo de ver mulher pelada em cenas de sexo (sem conectá-las com as personagens e a estória contada pelo filme) parece de algum modo ajustado ao efeito de excitação sexual visado pela pornochanchada e à maneira como nela as cenas de nu e sexo muitas vezes se desconectam bizarramente da narrativa e ganham uma involuntariamente ousada gratuidade. Ou seja: neste desejo de ver (ou nesta pulsão escópica) o cinema não estaria sendo reconhecido como arte ficcional, mas, apoiado no inequívoco valor documental de seus milhares de fotogramas, estaria sendo um mero meio de conhecimento do mundo (em um de seus elementos mais decisivos: o outro do sexo) e de voluptuosa iniciação (ainda que apenas por meio da imagem) em um de seus mais prazerosos mistérios. Mas isso em si - para escândalo dos bons moralistas do trabalho - não chega a ser um mal, assim como não o é a presença mesma do sexo na pornochanchada, mas sim o fato de ele ser tímido e mal representado (cf. Jean-Claude Bernardet: "A maior falha dessa 
pornochanchada não é ser pornô, mas ser muito pouco pornô” ${ }^{35}$ ), compondo uma estória débil e cretina com personagens muito pouco convincentes e uma visão de mundo afinal pobre, tacanha e convencional. Uma longa passagem sobre a pornochanchada no ensaio "Cinema: trajetória no subdesenvolvimento" de Paulo Emílio Sales Gomes, cujas exemplares ironia e lucidez justificam sua citação aqui, parece desembocar em uma sugestão análoga à que vínhamos ensaiando: “O estilo é próximo dos documentos publicitários cheios de fartura, ornamentados por imagens fotogenicamente positivas do ocupado e pelo bamboleio amável de quadris nas praias da moda, combinadas ao louvor de autoridades militares e civis. Essa simultaneidade audiovisual um pouco insólita não significa que um setor qualquer do poder público tenha inspirado - dentro da fórmula de que hoje o circo complementar do pão é o sexo - o erotismo que irrompeu no cinema brasileiro de uns anos para cá. A idéia divertida infelizmente não é verdadeira; foi certamente propalada por espíritos desconfiados e insensatos, mas chegou a intrigar as altas esferas. Essa facilidade de circulação da tolice nos tempos que correm esclarece em todo caso a relutância oficial diante do condimento mais atraente que possui o espetáculo de um Brasil milagroso, com muito apetite e tendo como satisfazê-lo, morando bem e vestindo melhor, trabalhando pouco e sem problemas de locomoção. $\mathrm{O}$ erotismo desses filmes, apesar do afobamento, da vulgaridade ineficaz, da tendência autodestruidora em acentuar nos quadris as nádegas e no seio a mama, é com efeito o que têm de mais verdadeiro, particularmente quando retratam a obsessão sexual da adolescência." 36

Paulo Emílio, afastando-se de qualquer moralismo burguês ingênuo, recupera assim o vital elemento básico da pornochanchada: aquele que justifica a primeira parte de seu nome composto. Não toca, no entanto, no possível elemento de humor ou comicidade (cujo efeito seria o riso) que a segunda parte do nome sugere (se inscrevendo também numa tradição cinematográfica brasileira) e que, por exemplo, a cena de Vera Fischer com

\footnotetext{
35 Apud ABREU, 1996, p. 81.

36 SALES GOMES, 1996, p. 106-107.
} 
os anões, em seu bizarro grotesco, teria retrospectivamente liberado. Ainda uma vez: não é a presença em si de elementos "baixos" (obscenos) ou de procedimentos como o duplo sentido, o trocadilho e a piada (além de toda a gama de recursos mímicos pastelônicos), facilmente reconhecíveis na pornochanchada, assim como não é também a paródia, o deboche ou o escracho, o que desqualifica estética e moralmente a pornochanchada, mas sim a maneira diluída e bem comportada como eles se apresentam nestas "comédias de costume" leves, meio moralistas ${ }^{37}$ e o mais das vezes muito sem graça. Assim, pois, o grotesco ocasional (e como se não de todo deliberado) da cena de Vera Fischer na cama com os anões só se torna mesmo um pensado princípio de estruturação (exacerbando-se delirantemente e contaminando o conjunto de cenas) em um filme - este, sim, engraçado - como Os monstros de Babaloo (1970) de Elyseu Visconti; assim como o deboche e escracho, educadamente presentes na pornochanchada, só serão inteiramente assumidos - e aí de maneira ostensivamente deliberada e programática - em um filme como O Bandido da Luz vermelha (1969) de Rogério Sganzerla ("Quando a gente não pode fazer nada, a gente se avacalha. A gente se avacalha e se esculhamba.”). No que é, portanto, o material específico (e tradicionalíssimo) do humor possível da pornochanchada: o sexo (e o obsceno), pode-se dizer serenamente que ela jamais conseguiu realizar plenamente o duplo sentido (tanto o objeto quanto a abordagem) do termo sacanagem (precedido pela preposição de), fazendo de fato "filmes de sacanagem", sendo que também aí é o chamado "cinema marginal" quem logo vai explorar mais radicalmente estas possibilidades (abandonando-as pouco depois, senão no caso de Carlos Reichenbach) - apesar de não ter conseguido criar um filão comercial duradouro como projetava o "Manifesto do Cinema Cafajeste" de João Callegaro - em filmes como As Libertinas (1968) de Carlos Reichenbach, Antonio Lima e João Callegaro,

\footnotetext{
${ }^{37}$ Cf. Ody Fraga: "Não apareceu uma pornochanchada que chegasse a contestar as estruturas e os preconceitos sexuais (...). Pelo contrário, ela sempre reforçou o amor idealizado à maneira das estruturas burguesas estabelecidas" (ABREU, 2006, p. 166).
} 
Audácia! (1970) de Carlos Reichenbach e Antonio Lima, O pornógrafo (1970) de João Callegaro, $A$ mulher de todos (1969) e Copacabana mon amour (1970) de Rogério Sganzerla, filmes sobre os quais óbvia e infelizmente eu não tinha na época nenhuma informação (sendo que mesmo nos melhores cine-clubes belo-horizontinos - organizados por uma esquerda "séria" - o máximo que se conseguia ver na segunda metade dos anos 70 era $O$ bandido da luz vermelha).

Feito, porém, este inevitável e necessário juízo de valor moral-estético discriminando a radicalidade do "cinema marginal" e a diluição eróticocômica da pornochanchada, podemos por um instante lembrar, em certos casos, a confluência dessas duas correntes em um mesmo meio de produção de cinema: a lendária Boca do Lixo paulista. É, por exemplo, Antônio Polo Galante (até 1975 junto com Alfredo Palácios na Servicine), homem de negócios esperto formado na vida (e surgido do acaso ${ }^{38}$ ), grande produtor de pornochanchadas (em seus mais variados gêneros) nos anos 70 , quem vai produzir $A$ trilogia do terror (1968) de Ozualdo Candeias, Luís Sérgio Person e José Mojica Marins, $A$ mulher de todos (1969) de Sganzerla, $O$ pornógrafo (1970) de João Callegaro, A guerra dos pelados (1970) de Sylvio Back e A Selva (1973) de Márcio Souza, assim como mais tarde (já separado de A. Palácios, que cria a Kinoarte Filmes) nas Produções Cinematográficas Galante ele produzirá A ilha dos prazeres proibidos (1977) e Império do desejo (1978) de Carlos Reichenbach. Ora, a grande virada na vida empresarial de Galante, a produção de Vidas nuas a partir do inacabado Erótica de Ody Fraga, rendendo bem com produção barata e inaugurando o filão pornochanchádico, foi feita em parceria com Sylvio Renoldi como montador, ${ }^{39}$ o mesmo Sylvio Renoldi que montou $A$ hora e a vez de Augusto Matraga (1965, Prêmio do Festival de Brasília) e O bandido da luz vermelha (1968, Prêmio INC). E, outro exemplo possível, um diretor de pornochanchadas como Jean Garret, praticamente ignorado pela crítica séria, teve Carlos Reichenbach como diretor de fotografia em Excitação,

\footnotetext{
${ }^{38}$ Cf. ABREU, 2006, p. 30.

${ }^{39}$ Cf. ABREU, 2006, p. 31.
} 
Mulher, mulher, A força dos sentidos e outros, teve João Silvério Trevisan como roteirista em $A$ mulher que inventou o amor e Inácio de Araújo também como roteirista em $O$ fotógrafo. A pornochanchada era assim para os realizadores ou criadores de cinema uma economicamente não desprezível (apesar de desprezada pelo preconceito comum e pela crítica séria) possibilidade de continuar fazendo cinema. Que o ponto de vista de quem então fazia cinema poderia ser menos exclusivo e mais impuramente misturado (privilegiando antes a alegria de fazer cinema) é o que sugere um depoimento como o de Guilherme de Almeida Prado (depois reconhecido pela crítica séria por seu $A$ dama do Cine Xangai): "Eu acho que só depois de $A$ dama do Cine Xangai é que esse preconceito realmente desapareceu. Mas quando eu estava trabalhando na Boca eu não prestava a menor atenção nisso. Nessa época não me incomodava nada. Eu estava fazendo cinema, que era o que eu queria fazer, e estava muito feliz." ${ }^{\prime 0}$ Ou de Inácio de Araújo: "Eu me divertia. Eu fazia pornochanchada também e fazia outros filmes, fazia publicidade. (...) Esse papo [de preconceito] é coisa de quem não entende, porque pra quem gosta de cinema, tanto faz como tanto fez se o filme tem sexo ou deixa de ter." ${ }^{11}$ Ou mesmo a ainda mais impura e radicalmente assumida alegria de fazer... amor (proporcionada pelas filmagens), segundo o corajoso depoimento de Carlos Reichenbach sobre o Cinema Marginal: "De 67 a 71, o cinema era apenas um apêndice da vida. Filmei meu episódio em As libertinas mais interessado em aplicar as liçôes do Kama-sutra com a namorada nas areias da locação, enquanto buscava os ângulos mais absurdos para filmar cavalos e excrementos na praia." ${ }^{42}$

Do decisivo ponto de vista econômico (que é também o de uma política estatal de mercado) pode-se desacreditar inteiramente a hipótese (que se tornou um lugar-comum) de José Carlos Avellar de que "Antes de mais nada, a pornochanchada é uma invenção da Censura." ${ }^{43} \mathrm{~A}$

\footnotetext{
${ }^{40}$ ABREU, 2006, p. 169-170.

${ }^{41}$ ABREU, 2006, p. 170.

${ }^{42}$ PUPPO, 2004, p. 126.

${ }^{43}$ AVELLAR, 2005, p. 340.
} 
pornochanchada (assim como parte do Cinema Marginal produzido na Boca do Lixo) teria sido antes um resultado da lei, promulgada em 1967 pelo INC, de obrigatoriedade de exibição para o filme brasileiro (integrando-se em uma política de substituição das importaçôes e incentivo à produção de um similar nacional) que em 1967 tem uma cota de 56 dias por ano, em 1969 a de 63 dias e em 1975 (o seu auge) a de 115 dias. ${ }^{44}$ Já que a lei obrigava realmente os exibidores a passarem filmes brasileiros, aqueles, "(...) tradicionalmente a serviço da distribuição internacional, começaram a se associar ou mesmo a co-produzir filmes, lucrando como exibidores e como produtores", ${ }^{45}$ obviamente atentos ao possível rendimento com o público popular que então freqüentava as salas de cinema dos centros das grandes cidades por um preço acessível (de que hoje, com ingressos a 6, 7 dólares, já nos esquecemos totalmente) de apenas 80 cents de dólar. ${ }^{46}$ Ainda que o resultado artístico da fórmula "erotismo, produção barata e público numeroso" tenha sido - na maioria dos casos mais do que duvidoso, é fato que a rara conjunção entre exibidores e produtores brasileiros na primeira metade dos anos 70 estimulou quantitativamente a produção de cinema brasileiro, realizando algo que só aconteceu no Brasil no período áureo das chanchadas (anos 50) e na chamada "bela época do cinema brasileiro" entre 1908 e $1911 .{ }^{47}$

Mas pode-se duvidar também - como o fez Paulo Emílio na passagem maior citada há pouco - de que a também moralmente conservadora ditadura militar (ainda que preferindo certamente a pornochanchada aos filmes "comunistas" do Cinema Novo ou "escrachados" do Cinema Marginal) tivesse algum interesse direto na liberação dos costumes ou na simples exposição de nus ou de sexo (mesmo tímidas),

\footnotetext{
${ }^{44}$ Cf. ABREU, 2006, p. 17.

${ }^{4}$ ABREU, 2002, p. 12.

46 Cf. ABREU, 2002, p. 12.

${ }^{47}$ Cf. Paulo Emílio Sales Gomes: “Tal entrosamento entre o comércio de exibição cinematográfica e a fabricação de filmes explica a singular vitalidade do cinema brasileiro entre 1908 e 1911.” (SALES GOMES, 1996, p. 24).
} 
como bem o provam os inumeráveis cortes pela censura de cenas ou falas eroticamente mais ousadas nas pornochanchadas. Tendemos hoje a esquecer facilmente a limitação dos meios de comunicação desta época (ausência de Internet, TV a cabo e videolocadoras) assim como o corrente conservadorismo familiar nos costumes sexuais, minimizando quase inevitavelmente a (para os esclarecidos tímida, convencional e tola) liberação dos temas sexuais na pornochanchada, que então não fazia senão acompanhar medrosa e canhestramente a revolução sexual pós-movimento hippie e pós-maio de 68 e o crescente interesse mundial pelo cinema erótico/pornográfico. Ainda que facilmente criticável como ingênuo e passivo voyeur, ${ }^{48}$ o espectador popular (ou adolescente) de pornochanchada poderia de fato estar encontrando nelas algum elemento de liberação (ou distensão) em meio à repressão sexual ainda quase generalizada, satisfazendo de algum modo (que não ousaríamos chamar de ilegítimo) a curiosidade e o desejo de excitação, tal como sugere este depoimento de Jean-Claude Bernardet: "Cheguei a fazer algumas pequenas experiências com pessoas, tipo operários. Passava os filmes - pornochanchadas-e depois conversávamos para ver o que estavam apreendendo. Eles estavam apreendendo coisas que eu não estava. E as que eu apreendia eles interpretavam diferentemente. Girava em torno de sexo e comportamento. Nós tínhamos uma tendência a ver nos filmes atitudes muito moralistas, com valores até retrógrados. Eles viam como libertação sexual, escapar a um moralismo, escapar das tensões." ${ }^{49} \mathrm{E}$ - para além do mero Ersatz que seria o prazer do auto-erotismo de voyeur - uma possível dimensão prática da pornochanchada (sobretudo para o adolescente) de informação e iniciação transgressiva (mesmo se atenuada) em um assunto vital sobre o qual por pudor nada ou muito pouco se falava ou se mostrava então é o que (por analogia com o pornô, aí o objeto da fala,

${ }^{48}$ Cf. Matilde Mastrangi: "O público que via pornochanchada era o 'zé mané'. Ele ia ver sexo. (...) O que me incomodou foi esses homens irem ao cinema bater punheta. Que tipo de homem eu estou incentivando? Ele tem mais é que ter uma mulher, ter sexo com essa mulher." (ABREU, 2006, p. 164). 49 ABREU, 2006, p. 155. 
mas curiosamente o seu maior algoz) sugere este experiente e franco depoimento de Ozualdo Candeias: "O sexo explícito, enquanto trazia uma informação erótica, sado-erótica ou o diabo que fosse, existiu. Primeiro, porque até o [aparecimento do] sexo explícito, e esse é um dos valores dele, ninguém sabia bem como fazer, como trepar, quem chupava ou dava o rabo. Era um crime desgraçado. Com o [filme de] sexo explícito isto se tornou um pouco normal, porque esses comportamentos eram intrínsecos de determinadas personalidades. Quando isso foi mais ou menos liberado, por causa desse cinema, deixou de haver um bocado de gente bloqueada. [...] Coisa que antes disso não havia. Estou falando da importância deles [dos filmes de sexo explícito], né? Importante para a liberação." ${ }^{0}$

Mas foquemos agora, uma última vez, o elemento vital que, para a atenção curiosa do adolescente, ultrapassava em muito o cinema visto e pensado como arte: o sexo. Se a própria pornochanchada, em voga sobretudo na segunda metade dos anos 70, de algum modo realiza internamente a desconexão entre (a nudez e) o sexo e a narrativa representada por personagens, e se algumas salas de cinema - como o Candelária - tendem a se especializar nesse tipo de filme, afastando um público burguês sério e se convertendo em um espaço erótico sujo e maldito (no caso, ladeado por muitos bares na Raul Soares e opçóes de hotel barato nas imediaçôes), talvez seja possível pensar uma estranha e surpreendente analogia com os primeiríssimos filmes pornográficos (isto é: dos últimos cinco anos do século XIX e da primeira metade da primeira década do séc. $\mathrm{XX}$ ) - anteriores à constituição de uma narrativa (um gênero literário segundo o molde ficcional realista do século XIX) no cinema - e também com os locais iníquos (music-halls e vaudevilles) em que eram passados para um público predominantemente masculino dos "segmentos mais pobres e mais desclassificados culturalmente da população". ${ }^{1}$ Tanto em um caso quanto no outro teríamos algo como um "aquém do cinema", uma mera forma "baixa" e popular de divertimento.

\footnotetext{
50 ABREU, 2006, p. 129.

${ }^{51}$ MACHADO, 1997, p. 79.
} 
Arlindo Machado lembra em "Pré-cinemas: o cinema das origens" (em Pré-cinemas \&́ pós-cinemas) que este pré-cinema "(...) reunia, na sua base de celulóide, várias modalidades de espetáculos derivadas das formas populares de cultura, como o circo, o carnaval, a magia e a prestidigitação, a pantomima, a feira de atraçōes e aberrações etc.", caracterizando este mundo - via Mikhail Bakhtin - como sendo baseado "no princípio do riso e do prazer corporal", cujas formas de expressão (nomeadas por Bakhtin como realismo grotesco) "(...) compreendem um sistema de imagens em que o princípio material e corporal (comer, beber, defecar, fornicar) comanda o espetáculo e em que abundam os gestos e as expressóes grosseiras, as profanaçôes, as heresias e as paródias." 52

É ainda Arlindo Machado quem nos informa: "Não sendo técnica ou politicamente viável exercer a repressão pura e simples sobre essas formas de espetáculos ditas 'baixas' ou 'vulgares', optou-se pelo seu confinamento em guetos, em geral situados nas periferias, próximos aos cordóes industriais, onde a diversão suspeita misturava-se facilmente com a prostituição e a marginalidade. Foi aí, nesses lugares iníquos, que o cinematógrafo nasceu e tomou força durante os seus 10 ou 20 primeiros anos. (...) Eram locais bastante populares e também um tanto malafamados por causa da atmosfera plebéia e do 'baixo nível' dos espetáculos burlescos ali encenados. Na verdade, os vaudevilles eram abominados pelas platéias sofisticadas e pelas pessoas de 'boa família'. Quando, num primeiro momento, a venda de álcool era ainda tolerada nesses locais e a prostituição florescia ao seu redor, não era difícil que uma visita a uma dessas casas se transformasse em bebedeira, quebra-quebra ou aventura sexual." ${ }^{13}$

Vejamos, enfim, com Arlindo Machado, o repertório genérico destes filmes e nele, mais particularmente, o gênero pornográfico (e o comportamento por ele suscitado): "No período que vai de 1895 (data das primeiras exibições públicas do cinematógrafo dos Lumière) até meados da primeira

\footnotetext{
52 MACHADO, 1997, p. 76-77.

${ }^{53}$ MACHADO, 1997, p. 77-78.
} 
década do século seguinte, os filmes que se faziam compreendiam registros dos próprios números de vaudeville, ou então atualidades reconstituídas, gags de comicidade popular, contos de fada, pornografia e prestidigitação. Os catálogos dos produtores da época classificavam os filmes produzidos como 'paisagens', 'notícias', 'tomadas de vaudeville', 'incidentes', 'quadros mágicos', 'teasers' (eufemismo para designar a pornografia) etc. (...) A pornografia, como não podia deixar de ser, corria solta. A Biograph americana e a Pathé francesa transformaram o erotismo em uma de suas especialidades. Cenas de adultério, mulheres se despindo para ir para a cama, personagens míticas fazendo amor, tudo era válido para excitar uma platéia já por si só bastante suscetível. A Biograph produziu vários filmes curtíssimos destinados sobretudo aos peep-shows (...), nos quais atrizes seminuas davam piscadinhas cúmplices para o espectador, implicando-o abertamente como voyeur dentro do cinema. Na França, a Pathé também explorava o nu frontal, sobretudo nos pequenos filmes destinados à exibição nos mutoscópios (...). Nos music-halls e café-concerts, era bastante comum um gênero de filmes conhecidos como tableaux vivants (...), que mostrava basicamente mulheres em maiôs colantes ou em trajes sumários, congeladas em gestos provocantes. A masturbação na sala escura acabou por se converter em prática regular e disseminada, verdadeiro ato de provocação coletiva, que resistiria a todas as formas de policiamento." 54

Semelhante uso - “imoral”, segundo a moral puritana (ou "revolucionária") do trabalho - do cinema foi previsto imaginária e inauguralmente por Máximo Gorki em artigo escrito já em 1896, como lembra Paulo Emílio Sales Gomes ao discutir as semelhanças entre "Cinema e prostituição" (em Crítica de cinema no Suplemento Literário vol. II): "Tratava-se de uma reportagem sobre a apresentação na Rússia dos primeiros filmes de Lumière. Evidentemente não foi o conteúdo dos filmes apresentados - A chegada de um trem, Saida de operários da fábrica, $O$ lanche do bebê, ou L'arroseur arrosé - que provocou a meditação de Gorki, mas precisamente o contraste entre a natureza documental, familiar e

${ }^{54}$ MACHADO, 1997, p. 80-81. 
ingênua desses registros cinematográficos e o ambiente particular do local onde eram projetados. As exibiçōes foram feitas durante a Feira Anual de Nijri-Novgorod num estabelecimento pertencente a um certo Charles Aumont (...). O pavilhão de Aumont é fustigado como um lugar onde apenas o vício é encorajado e popularizado. O público era composto, segundo Gorki, de vitimas das misérias sociais e o escritor completa o quadro ao aludir com moderação a vadios que compram beijos e às mulheres que os vendem. Gorki sublinha o que havia de insólito na apresentação das imagens simples ou bucólicas dos Lumière no Concert Parisien - tal era a denominação do estabelecimento de Charles Aumont - e manifesta a convicção de que logo esses filmes seriam substituídos por outros cujos títulos, aliás, ele sugere: Como Ela se Despe, Madame no Banho, ou ainda A Mulher de Meias, já que naquele tempo de vestidos até o pé (...) a simples idéia de meias femininas evocava, por si só, todo um universo erótico." 55

Paulo Emílio comenta então a maneira moralista ("revolucionária") como é feita por Gorki esta aproximação: "Para a ideologia revolucionária de Gorki, aliás bastante difusa, a prostituição aparecia como a conseqüência direta de uma sociedade injusta. (...) Aos seus olhos o mundo que combatia não podia deixar de aceitar plenamente a prostituição, pois no caso contrário esse mundo estaria negando-se a si próprio. Quando o escritor observou, entre os delineamentos seguidos pelo cinema, a confirmação de suas previsões, não teve dúvidas em considerar a maioria dos filmes como fazendo parte, com a prostituição, o alcoolismo e outras taras, da sintomatologia geral de um mundo doente." 56

Paulo Emílio, no entanto, - na contra-mão deste "revolucionário" Gorki que, como Lenine, "era severo em matéria de moral e convencional em arte", e não sem antes algumas precauções ("não gostaria nada de me ver acusado de simpatizar com a prostituição ou mesmo, quem sabe lá, de encorajá-la, ou então de estar denegrindo o cinema”) - se sente à vontade “(...) para observar que de um certo ângulo as necessidades que o cinema e

\footnotetext{
55 SALES GOMES, 1981, p. 363.

${ }^{56}$ SALES GOMES, 1981, p. 364.
} 
a prostituição satisfazem são as mesmas, e que essas necessidades talvez não estejam obrigatoriamente, e ao invés do que pensava Gorki, condicionadas a esta ou aquela estrutura social, mas que sejam expressão de algo permanente no homem. Dizer que os espectadores entram no cinema como vão, ou iriam, ao bordel, não deixa de ser chocante, mesmo atenuando-se bastante a idéia com o acréscimo de que isso sucede sob um ângulo bem particular de exame, ou ainda com a explanação de que a palavra bordel resume aqui a gama imensa de estabelecimentos e instituiçóes que vai do prostíbulo mais miserável ao conforto moderno das call-girls. E no entanto é um pouco isso que acontece. Para os propósitos deste artigo basta aludir a algumas significações muito nítidas do fenômeno Brigitte Bardot, ou lembrar que, se para uma boa parte do público feminino, Rodolfo Valentino era um príncipe encantado, para outro setor igualmente considerável do mesmo público, ele era sobretudo um imaginário gigolô. Tenho os mais jovens em menor medida, e os adultos preclaros e menos chocantes se, invertendo agora a maneira de ver as coisas, eu lembrar que com muita freqüência os homens vão ao bordel como se fossem ao cinema. É evidente que a procura de prostitutas não pode ser interpretada em termos exclusivos de descarga sexual, sob o risco de total obscurecimento do problema que nos ocupa. Os homens, os mais jovens em menos medida, e os adultos plenamente, vão ao bordel em busca de ficção." ${ }^{57}$

57 SALES GOMES, 1981, p. 364-365. Com uma perspectiva historicamente mais abrangente e distanciada do que a de Gorki (e abstraindo de qualquer conteúdo erótico eventual dos filmes ou da localização de suas projeçôes em espaços urbanos iníquos), Walter Benjamin - em "L'œuvre d'art à l'époque de sa reproductibilité technique" - percebeu na nova forma de arte que é o cinema uma relação diferenciada do espectador com a obra, relação que (própria a um novo modo de existência urbana) é caracterizada não mais pela concentração - como, por exemplo, com a pintura - mas pela distração (ou, nos termos de uma paradoxal transposição sensorial, não mais pela contemplação, mas pelo toque): "De espetáculo atraente para o olho ou de sonoridade sedutora para a orelha, a obra de arte, com o dadaísmo, se fez projétil. O receptor era atingido por ela. A obra adquiriu uma qualidade tátil. Ela favoreceu assim a 


\section{Referências bibliográficas}

ABREU, Nuno César. O olhar pornô: a representação do obsceno no cinema e no vídeo. Campinas: Mercado de Letras, 1996.

ABREU, Nuno César. Boca dos Sonhos (Pesquisador aborda a 'Boca do Lixo', epicentro da indústria da pornochanchada). In: SUGIMOTO, Luiz. Boca dos Sonhos. Jornal da Universidade Estadual de Campinas, 16 a 22/12/2002, p. 12.

ABREU, Nuno César. Boca do lixo: cinema e classes populares. Campinas: Editora da Unicamp, 2006.

demanda por um mercado cinematográfico, pois o aspecto de distração do filme tem, também ele, em primeiro lugar um caráter tátil, em razão das mudanças de lugares e de plano que assaltam o espectador em golpes sucessivos. Que se compare a tela sobre a qual se desenrola o filme com a tela sobre a qual está fixada a pintura. Esta última convida o espectador à contemplação; diante dela, ele pode se abandonar a suas associações de idéias. Nada disso diante das apreensões de imagens do filme. Mal o olho apreendeu, elas já se transformaram. Impossível fixá-las. Duhamel, que detesta o cinema e que não compreende nada de sua significação, mas não sem ter captado alguns elementos de sua estrutura, sublinha este caráter quando escreve: 'Não posso mais pensar o que quero. As imagens em movimento substituem meus próprios pensamentos.' Efetivamente o processo de associação do espectador que olha estas imagens é imediatamente interrompido pela metamorfose delas. É daí que vem o efeito do choque exercido pelo filme e que, como todo choque, só pode ser amortecido por uma atenção reforçada." (BENJAMIN, 2000, p. 309). A nota de pé-de-página indicada ao fim da frase que termina esta passagem citada diz o seguinte: "O filme é a forma de arte que corresponde à vida cada vez mais perigosa que o homem de hoje deve enfrentar. A necessidade de se expor aos efeitos de choque é uma adaptação dos homens aos perigos que os ameaçam. O cinema corresponde a modificações profundas do aparelho perceptivo, aquelas mesmas que hoje são vividas, na escala da vida privada, pelo primeiro transeunte surgido em uma rua de grande cidade, e, na escala da história, por qualquer cidadão de um Estado contemporâneo.” (BENJAMIN, 2000, p. 309). 
ALBANO, Celina. Cine Pathé (Coleção BH. A cidade de cada um). Belo Horizonte: Conceito Editorial, 2008.

APULÉE. Les Métamorphoses ou l'Âne d'or. Texte établi par Robertson, D. S. et traduit par Sers, Oliviers. Paris: Les Belles Lettres, 2007.

ARAÚJO, Vicente de Paula. Salóes, circos e cinemas de São Paulo. São Paulo: Perspectiva, 1981.

ARMANDO, Carlos. A sala dos sonhos. Belo Horizonte: C/Arte, 1999.

AVELLAR, José Carlos. A teoria da relatividade. In: NOVAES, Adauto (Org.). Anos 70: ainda sob a tempestade. Rio de Janeiro: Aeroplano/Senac Rio, 2005. p. 337-373.

BATAILLE, Georges. Kinsey, a escória e o trabalho. In: O erotismo: o proibido e a transgressão. Trad. J. Bernard da Costa. 2. ed. Lisboa: Moraes Editores, 1980. p. 133-146.

BENJAMIN, Walter. L'œuvre d'art à l'époque de sa reproductibilité technique (dernière version de 1939). Trad. Gandillac, Maurice de. In: Oeuvres III. Paris: Gallimard, 2000. p. 269-316.

BRAGA, Ataídes. O fim das coisas: as salas de cinema de Belo Horizonte. Belo Horizonte: Centro de Referência Áudio-Visual/PBH, 1995.

CIORAN, E. M. Michaux: a paixão do exaustivo. In: Exercícios de admiração-Ensaios e perfis. Trad. Brum, José Thomaz. Rio de Janeiro: Rocco, 2000. p. 91-96.

GOMES, Paulo Augusto. 100 anos de cinema em Belo Horizonte. In: Varia História 18: Belo Horizonte - cem anos em cem, novembro de 1997. p. 347-372.

KRACAUER, Siegfried. Cinéma dans la Münzstrasse. In: Rues de Berlin et d'ailleurs. Trad. Boutout, Jean-François. Paris: Gallimard, 1995. p. 102-104.

MICHAUX, Henri. Le merveilleux normal. In: Les grandes épreuves de l'esprit. Paris: Gallimard, 1966. p. 7-34.

MICHAUX, Henri. Comment agissent les drogues? In: Connaissance par les gouffres. Paris: Gallimard, 1967. p. 7-31.

MICHAUX, Henri. Quelques renseignements sur cinquante-neuf années d'existence. In: BELLOUR, Raymond (Org.). Henri Michaux-Cahiers de l'Herne. 2. ed. Paris: Éditions de l'Herne, 1983. p. 11-15. 
MACHADO, Arlindo. Pré-cinemas: o cinema das origens. In: Pré-cinemas \& pós-cinemas. Campinas: Papirus, 1997. p. 75-170.

NAVA, Pedro. Beira-mar. 3. ed. Rio de Janeiro: Nova Fronteira, 1985.

PUPPO, Eugênio (Org.). Cinema marginal brasileiro e suas fronteiras. 2. ed. São Paulo: Centro Cultural do Banco do Brasil, 2004.

SALES GOMES, Paulo Emílio. Cinema e prostituição. In: Crítica de cinema no Suplemento Literário vol. II. Rio: Paz e Terra, 1981. p. 363-367.

SALES GOMES, Paulo Emílio. Cinema: trajetória no subdesenvolvimento. In: Cinema: trajetória no subdesenvolvimento. Coleção Leitura. São Paulo: Paz e Terra, 1996. p. 85-111.

SALES GOMES, Paulo Emílio. Panorama do cinema brasileiro: 1896/1966. In: Cinema: trajetória no subdesenvolvimento. Coleção Leitura. São Paulo: Paz e Terra, 1996. p. 19-83. 


\section{Resumo}

Esta crônica-ensaio quer reconstituir - também a partir da memória pessoal - um período da história de uma sala de cinema belo-horizontina, o Cine Candelária, ou seja: os anos 70 e 80 (do século $\mathrm{XX}$ ) nos quais ocorrem a eclosão da pornochanchada e do pornô, a introdução massiva do vídeo-cassete e a decadência das salas de cinema nas grandes cidades brasileiras. Ela visa também a apresentar rapidamente e a tentar repensar dentro de seu contexto histórico-social um gênero "baixo" que foi em geral desprezado pela crítica séria: a pornochanchada.

\section{Résumé}

Cette chronique-essai veut reconstituer - à partir de la mémoire personnelle aussi - une période de l'histoire d'une salle de cinéma de Belo Horizonte, le Cine Candelária, c'est-à-dire : les années 70 et 80 (du XXème siècle) où ont lieu l'éclosion de la pornochanchada e du porno, l'introduction massive de la vidéocassete et la décadence des salles de cinéma dans les grandes villes brésiliennes. Elle vise aussi à présenter rapidement et à essayer de repenser dans son contexte socio-historique un genre "bas" qui a été en général méprisé par la critique sérieuse: la pornochanchada. 